\author{
Bruce C. Richardson ${ }^{\circ}$, \\ Narendra D. Lalwani $\diamond$, \\ Kent J. Johnson" and \\ Rory M. Marks ${ }^{\circ}$
}

Departments of Internal Medicine ${ }^{\circ}$ and Pathology", University of Michigan, Ann Arbor, Ann Arbor Veterans Administration Hospital ${ }^{\wedge}$ and Department of Pathology \& Experimental Toxicology Parke-Davis Pharmaceutical Research, Warner-Lambert Co. $\diamond$, Ann Arbor

\section{Fas ligation triggers apoptosis in macrophages but not endothelial cells*}

The reticuloendothelial system includes macrophages and endothelial cells. These cells are produced and destroyed in vivo with a precision that implies the existence of homeostatic mechanisms. The stimuli for endothelial cell proliferation and monocyte production are becoming well characterized. However, the mechanisms involved in eliminating these cells are poorly understood. One mechanism involved in cellular elimination is apoptosis, which can be triggered in some cells by ligation of the Fas molecule. In this report we have investigated whether macrophages and endothelial cells express the Fas molecule, and whether Fas transmits an apoptosis-inducing signal in these cells. We demonstrate that macrophages express Fas and readily undergo apoptosis when cultured with anti-Fas. In contrast, while endothelial cells can express the Fas molecule, Fas ligation is insufficient to induce apoptosis. These results suggest differential regulation of Fas function among cells of the reticuloendothelial system, and imply different mechanisms of homeostasis.

\section{Introduction}

Endothelial cells and monocytes/M $\Phi$ are members of the reticuloendothelial system and share properties such as phagocytosis, antigen presentation, and involvement in coagulation and inflammatory mechanisms [1-3]. Monocytes are continuously produced in the bone marrow, but $M \Phi$ do not normally accumulate to large numbers in peripheral tissues. The molecules regulating monocyte production have been intensively studied, but the mechanisms eliminating the approximately $10^{10}$ monocytes produced daily [4] have not been well characterized. Similarly, the endothelium undergoes remodeling during development, inflammation and wound healing, with proliferation followed by endothelial cell death [5]. Again, signals promoting endothelial cell proliferation have been intensively studied, but signals that mediate endothelial cell death have not been well characterized.

One possible clue to mechanisms involved in $M \Phi$ and endothelial cell elimination comes from studies on T cells. We reported that $\mathrm{M} \Phi$ undergo programmed cell death, or apoptosis, after activating $\mathrm{CD} 4^{+} \mathrm{T}$ cell clones [4], although the mechanism triggering the apoptotic response was not identified. One molecule potentially involved in this response is Apo-1/Fas. Fas, a member of the TNF receptor gene family, is a $43-\mathrm{kDa}$ membrane protein that can transmit an apoptosis-inducing signal [6]. Interestingly,

[I 13172]

\footnotetext{
* This work was supported by PHS grants RO1 AI25526, RO1 AR42525, and P60 AR20557, and a Veterans Administration Merit Review grant.
}

Correspondence: Bruce Richardson, R4540 Kresge 1, Ann Arbor MI 48109-0531, USA (Fax: 313-7 63-2025)

Abbreviation: HUVEC: Human umbilical vein endothelial
cell

Key words: Endothelial cell / Macrophage / Fas protein / Apoptosis / Homeostasis activated $T$ cells express a functional Fas ligand [7], raising the possibility that $\mathrm{T}$ cells induce $\mathrm{M} \Phi$ apoptosis through Fas. However, Fas expression and function on MФ has not been characterized. Similarly, T cells lyse endothelial cells in an MHC-specific fashion [8]. Since $M \Phi$ and endothelial cells share the function of antigen presentation, it is possible that Fas-mediated apoptosis is involved in the elimination of both cell types.

In these studies we used confocal laser microscopy, flowcytometric analysis and immunoblotting to compare Fas expression and function on $\mathrm{M} \Phi$ and endothelial cells. We demonstrate that a subset of endothelial cells and $M \Phi$ express the Fas molecule. In addition, IFN- $\gamma$ is shown to cause an increase in Fas expression on both cell types. However, ligation of endothelial cell Fas does not result in cell death, while $\mathrm{M} \Phi$ readily undergo apoptosis following Fas ligation. These observations may have relevance to understanding mechanisms regulating homeostasis of both cell types.

\section{Materials and methods}

\subsection{Endothelial cell culture and treatment}

Cultures of human umbilical vein endothelial cells (HUVEC) were established according to the method of Jaffe [9] and maintained as previously described [10]. Cultured cells were identified as endothelial on the basis of typical morphology at confluence, and by positive immunofluorescence with antibody to human von Willebrand factor (CalBiochem, San Diego, CA). Proliferation of HUVEC was induced with basic fibroblast growth factor $(10 \mathrm{ng} / \mathrm{ml}$, Synergen, Boulder, $\mathrm{CO}$ ) supplemented with bovine lung heparin $0.1 \mu \mathrm{g} / \mathrm{ml}$ (Sigma Chemical Co., St. Louis, MO). Growth factors were withdrawn $24 \mathrm{~h}$ preceding assessment of Fas expression and other assays. Where indicated, media was replaced with fresh medium containing recombinant human IFN- $\gamma$ 10-1000 U/mI (Boehringer Mannheim, Indianapolis, IN) for $18-24 \mathrm{~h}$. Fixation was performed with $1 \%$ formaldehyde in PBS for $18 \mathrm{~h}$ at $4^{\circ} \mathrm{C}$. 


\subsection{Isolation of $M \Phi$ and treatment}

PBMC were isolated from the venous blood of healthy volunteers and $\mathrm{M} \Phi$ isolated by adherence as described [4, 11]. $M \Phi$ were cultured in RPMI 1640 (GIBCO, Grand Island, NY) supplemented with FCS, penicillin and streptomycin as before $[4,11]$. Where indicated, IFN- $\gamma$ was added as described above.

\subsection{Detection of Fas by flow cytometry}

Monoclonal antibodies against Fas were obtained from Kamiya Biochemicals (Japan) or Upstate Biotechnology (Lake Placid, NY). Both antibodies are IgM and of murine origin, and recognize the same epitope on Apo-1/Fas. For flow-cytometric detection, cells were incubated with antiFas $(5 \mu \mathrm{g} / \mathrm{ml})$ in standard buffer (PBS supplemented with $1 \%$ horse serum and $0.1 \%$ sodium azide) at room temperature for $1 \mathrm{~h}$, washed with standard buffer, then incubated with 1:250 dilution of FITC-conjugated goat anti-mouse Ig (GAM-FITC) (Coulter, Hialeah, FL) for $1 \mathrm{~h}$ at room temperature. Negative controls included isotype-matched myeloma proteins (MOPC 104e, from Sigma) and positive controls included $\mathrm{a} \mathrm{mAb}$ to framework determinants on class I MHC molecules (AMAC, Westbrook, ME). FITClabeled cells were detected using an Epics Elite flow cytometer (Coulter) equipped with a 15-mW argon laser.

\subsection{Quantitation of Fas using confocal laser cytometry}

For confocal imaging, freshly isolated $M \Phi$ or primary HUVEC cultures were seeded into gelatin-coated two-well Lab-Tek coverglass chambers (Nunc, Inc., Naperville, IL) and incubated as described above. Confocal imaging was performed on an ACAS 570 laser cytometer (Meridian Instruments Inc., Okemos, MI) using a $1600-\mu \mathrm{m}$ pinhole and an argon laser set at $100 \mathrm{~mW}$ with scanning strength set at $5 \%$, with a $10 \%$ neutral density filter. FITC was excited at $488 \mathrm{~nm}$ and the emission detected with a photo-multiplier tube using a 575-nm dichroic short pass and 530-nm band pass filter. A $360-\mu \mathrm{m} \times 360-\mu \mathrm{m}$ area was scanned at $1 \mu \mathrm{m}$ step size and 32 samples/point. At least five areas randomly selected in each sample were analyzed and each experimental condition was measured in triplicate. Average fluorescence per cell was obtained by dividing the total integrated value by the number of data points in that cell. All experiments were repeated at least twice.

\subsection{Measurement of MФ cytotoxicity}

$\mathrm{M} \Phi$ cytotoxicity was measured by ${ }^{51} \mathrm{Cr}$ release as previously described $[4,11]$. M $\Phi$ apoptosis was confirmed by isolating DNA fragments followed by fractionation through agarose gels as described [4]. Briefly, $5 \times 10^{6} \mathrm{M} \Phi$ were cultured for $18 \mathrm{~h}$ with $2.5 \mu \mathrm{g} / \mathrm{ml}$ anti-Fas or an isotype-matched myeloma protein (MOPC 104e). The cells were recovered, washed, then lysed with buffer containing $0.2 \%$ Triton $\mathrm{X}-100$. Chromatin was sedimented by centrifugation, and fragmented DNA precipitated from the cytosolic fraction with ethanol. DNA was extracted and purified from the precipitate, then fractionated by electrophoresis through $1.2 \%$ agarose gels and stained with ethidium bromide.

\subsection{Measurement of endothelial cytotoxicity}

Killing of endothelial cells was measured using a fluorescent technique that assesses survival of viable cells. Calcein AM (Molecular Probes, Eugene, OR) is a non-fluorescent non-polar esterase substrate that passively crosses cell membranes, and is cleaved by cytoplasmic esterases releasing a polar fluorescent product that is retained by cells with intact plasma membranes. Only viable cells generate and retain fluorescent calcein, the basis of the viability test.

HUVEC were seeded at 20000 cells per well into gelatincoated (Sigma, $0.2 \%$ for $10 \mathrm{~min}$ ) $96-$ well tissue culture plates (Corning, Corning, NY), and allowed to form confluent monolayers for $48 \mathrm{~h}$ before being used. Cells were exposed to Fas antibody or other stimuli in culture medium. After incubation the cells were washed by replacing the medium twice with PBS. Cells were then exposed to $1 \mu \mathrm{M}$ Calcein AM in PBS for $30 \mathrm{~min}$ at $37^{\circ} \mathrm{C}$, and fluorescent emission detected with a CytoFluor 2300 plate fluorometer (Millipore Inc., Bedford, MA), using $485 \mathrm{~nm}$ excitation, and $530 \mathrm{~nm}$ emission filters. Microwells containing known numbers of cells were used to generate a standard curve of fluorescence versus cell number. This technique is capable of accurately quantitating viable cells over a range from 200 to 100000 cells per well (unpublished data).

\subsection{DNA analysis of apoptosis by flow cytometry}

HUVEC were first incubated with IFN- $\gamma$ for $18 \mathrm{~h}$ as described above to augment Fas expression. Control and IFN- $\gamma$-treated cells were then incubated with anti-Fas $(2.5 \mu \mathrm{g} / \mathrm{ml})$ at $37^{\circ} \mathrm{C}$ for $1 \mathrm{~h}$. Where indicated, the anti-Fas was cross-ligated with anti-IgM $(5 \mu \mathrm{g} / \mathrm{ml})$ (Sigma) for 4 and $18 \mathrm{~h}$. Cultured $M \Phi$ were similarly treated with anti-Fas, but without anti-IgM. All cells were then washed with PBS and stained with $10 \mu \mathrm{m}$ Hoechst 33342 at $37^{\circ} \mathrm{C}$ for $30 \mathrm{~min}$. Hoechst 33342 was excited at $325 \mathrm{~nm}$ by a $30-\mathrm{mW} \mathrm{He}-\mathrm{Cd}$ laser, and fluorescence detected with a 470-nm dichroic long pass filter together with a 460 -nm band pass filter.

\subsection{Immunoblotting}

HUVEC for immunoblotting were grown to confluence in gelatin-coated 10-cm diameter tissue culture dishes (Corning). Selected dishes were treated with IFN- $\gamma 100 \mathrm{U} / \mathrm{ml}$ for $24 \mathrm{~h}$. Culture medium was removed by washing twice with PBS, and the cells lysed in situ with $1 \mathrm{ml}$ of $0.5 \%$ sodium dodecyl sulfate containing $1 \mu \mathrm{g} / \mathrm{ml}$ leupeptin, $1 \mu \mathrm{g} / \mathrm{ml}$ aprotinin, $10 \mu \mathrm{g} / \mathrm{ml}$ soy bean trypsin inhibitor, and $1 \mu \mathrm{g} / \mathrm{ml}$ pepstatin. After $30 \mathrm{~min}$ at $4{ }^{\circ} \mathrm{C}$, the lysate was collected into a syringe, the DNA was sheared by passing repeatedly through a 26-gauge needle, the protein content measured with BCA protein assay reagent (Pierce, Rockford, IL), and kept frozen at $-80^{\circ} \mathrm{C}$.

Aliquots $(100 \mu \mathrm{g})$ of lysates (representing approximately $10^{5}$ cells) were electrophoresed through a $4-20 \%$ linear gradient SDS polyacrylamide gel, and electrotransferred to nitrocellulose membranes $(0.45 \mu \mathrm{m}$, Schleicher and Schuell, Keene, NH). Residual protein binding sites were blocked with $5 \%$ non-fat dry milk in Tris-buffered saline (TBS, $0.15 \mathrm{M}$ sodium chloride, $0.02 \mathrm{M}$ Tris, $\mathrm{pH}$ 7.6). After 
washing, Fas antibody or a control $\operatorname{IgM}$ myeloma protein was added in fresh blocking solution at $10 \mu \mathrm{g} / \mathrm{ml}$, and incubated at room temperature for $8 \mathrm{~h}$. Membranes were washed in TBS supplemented with Tween $200.05 \%$ (TTBS), incubated $1 \mathrm{~h}$ at room temperature with horseradish peroxidase-conjugated rabbit antibody to mouse IgM (Cappel, Malvern, PA) diluted 1/3000, the blot again washed with TTBS, and antibody binding detected using enhanced chemiluminescence (ECL kit, Amersham, Arlington Heights, IL).

\section{Results}

\subsection{Cultured endothelial cells and Mథ express the Fas antigen}

Initial experiments determined if cultured HUVEC and $M \Phi$ expressed the Fas antigen. To exclude the possibility that cells released from the culture plates with proteolytic enzymes have altered Fas expression, adherent cells were first analyzed in situ using confocal laser microscopy, then results compared to conventional flow cytometric analysis. In Fig. 1a and b, Fas expression on HUVEC and MФ is quantitated by laser microscopy. A subset of HUVEC express Fas which in serial experiments, expression was of a relatively low level. $M \Phi$ expressed relatively more Fas. Fig. $1 c$ and $d$ shows a similar experiment using flow cytometry to measure Fas expression. Compared to negative controls, approximately $18 \%$ of the HUVEC expressed Fas, while $36 \%$ of the $M \Phi$ expressed Fas.

It has been reported that IFN- $\gamma$ can increase Fas expression in some cell types [12], so the effect of this cytokine on HUVEC and MФ Fas expression was examined. Fig. 2

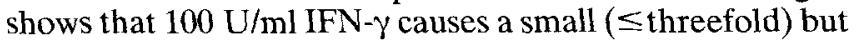
reproducible increase in Fas (mean channel fluorescence 0.78 on untreated HUVEC, and 2.27 on HUVEC treated with $100 \mathrm{U} / \mathrm{ml}$ IFN- $\gamma$ for $48 \mathrm{~h}$ ) using flow cytometry. Similar
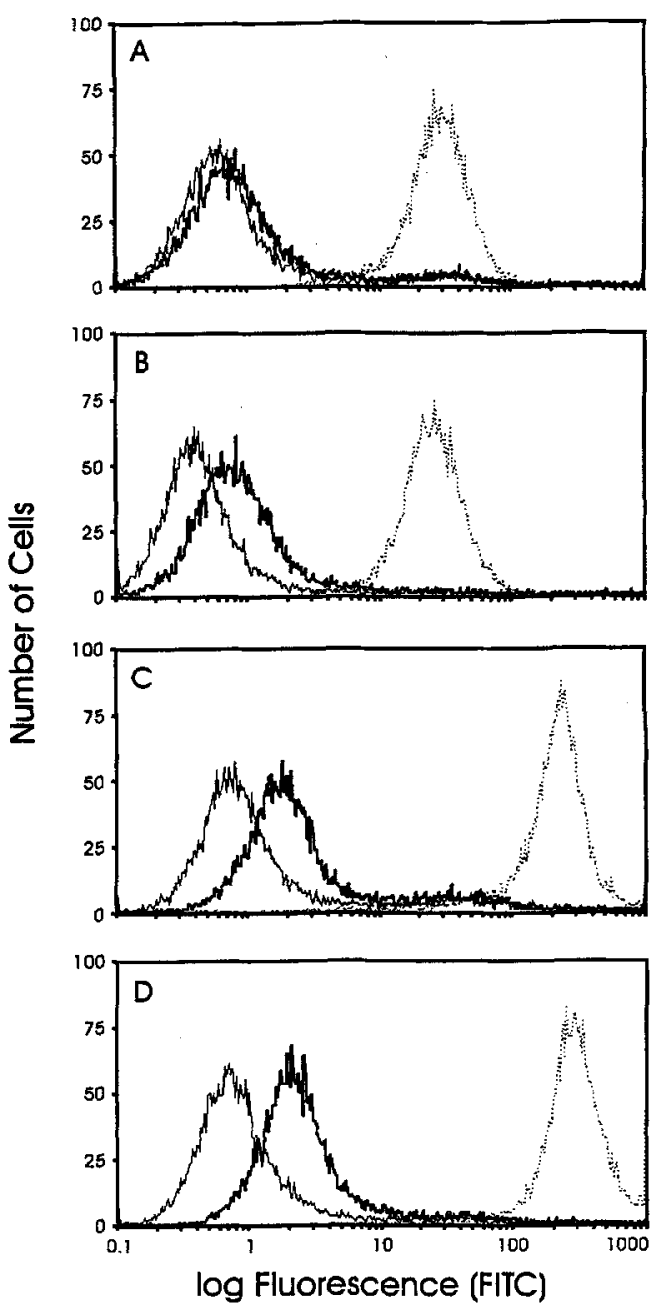

Figure 2. Relative expression of Fas on HUVEC after incubation in control medium for $48 \mathrm{~h}(\mathrm{~A})$, or treated with IFN- $\gamma, 100 \mathrm{U} / \mathrm{ml}$ for $4 \mathrm{~h}(\mathrm{~B}), 24 \mathrm{~h}(\mathrm{C})$ or $48 \mathrm{~h}$ (D). Flow-cytometric analysis shows reactivity of HUVEC with MOPC 104e (solid line, anti-Fas (bold-face line) and anti-HLA (dotted line).
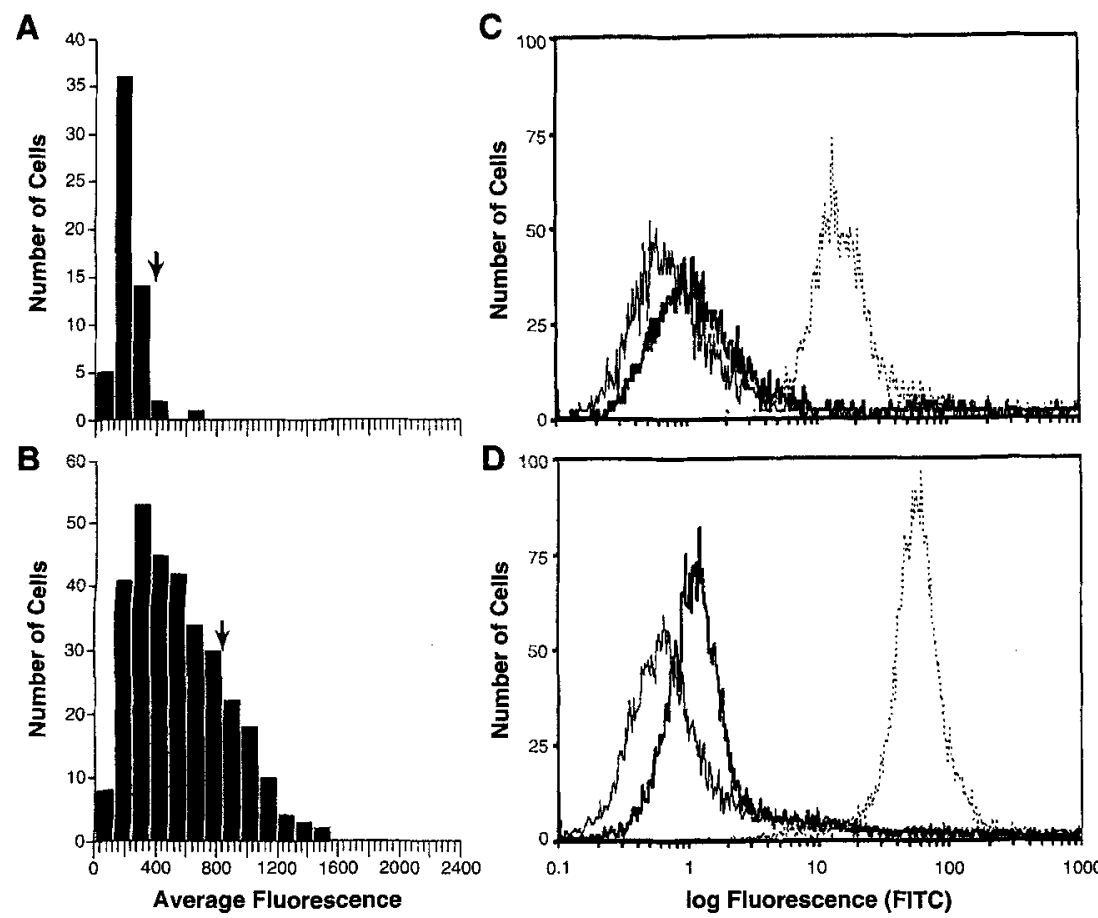

Figure 1. Fas expression on HUVEC and human $M \Phi$ quantitated by confocal laser scanning cytometry and flow cytometry. Panel A shows quantitative histograms of HUVEC incubated with anti-Fas and GAM-FITC, with fluorescence intensity relative to isotypematched control antibodies in arbitrary units on the $\mathrm{X}$ axis. The arrow identifies the highest level of fluorescence observed with the control myeloma protein. Panel B shows $M \Phi$ stained and analyzed similarly to the cells in panel $\mathrm{A}$. Panel $\mathrm{C}$ shows the relative expression of Fas on HUVEC and panel D shows Fas expression human $M \Phi$ measured by flow cytometry. The flow cytometric analysis was performed using control MOPC 104e (solid line), anti-Fas (boldface line) and anti-HLA (dotted line). The analysis of HUVEC shows that approximately $18 \%$ of the cells express fluorescence above control levels, and a mean fluorescence value of 1.3. Similar analysis of human $\mathrm{M} \Phi$ showed approximately $36 \%$ of the cells with fluorescence above that of control antibodies, and a mean fluorescence value of 1.45 . 
results were seen using 10 and $1000 \mathrm{U} / \mathrm{ml}$ IFN- $\gamma$ (not shown). Note that class I MHC also increases in expression following IFN- $\gamma$ treatment, as described earlier [13]. IFN- $\gamma$ induced a similar increase in $\mathrm{M} \Phi$ Fas expression as well (mean fluorescence 1.45 on untreated $\mathrm{M} \Phi$ and 2.74 on $\mathrm{M} \Phi$ treated with $1000 \mathrm{U} / \mathrm{ml} \mathrm{IFN-} \gamma$ for $24 \mathrm{~h}$ ). In a confirmatory experiment, performed using confocal laser microscopy, HUVEC were treated with with $10-1000 \mathrm{U} / \mathrm{ml}$ IFN- $\gamma$ for $24 \mathrm{~h}$. Again, a distinct (two- to threefold) increase in Fas expression relative to untreated cells was seen (not shown).

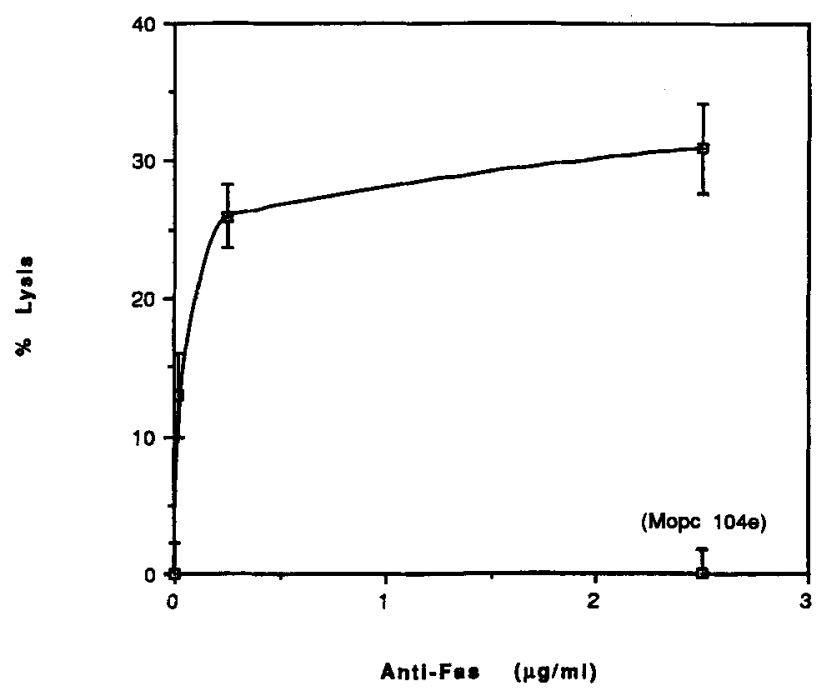

Figure 3. MФ death induced with anti-Fas. $M \Phi$ were labeled with ${ }^{5 !} \mathrm{Cr}$, then incubated $18 \mathrm{~h}$ with the indicated concentrations of anti-Fas or MOPC $104 \mathrm{e}$. Radioactive ${ }^{51} \mathrm{Cr}$ release was then measured as described in Sect. 2.5. Results represent the mean \pm SEM of quadruplicate determinations.

\subsection{Anti-Fas is cytotoxic to $\mathrm{M \Phi}$ but not to endothelial cells}

The ability of anti-Fas to induce apoptosis was then compared using $M \Phi$ and HUVEC. Fig. 3 compares $M \Phi$ cytotoxicity induced by MOPC $104 \mathrm{e}$ with anti-Fas as measured by chromium release. A maximum in cell death of approximately $30 \%$ was induced by $2.5 \mu \mathrm{g} / \mathrm{ml}$ anti-Fas, equivalent to the number of cells expressing Fas. No further increase was seen if the $M \Phi$ were pretreated for $18 \mathrm{~h}$ with IFN- $\gamma$ (not shown). DNA fragmentation studies demonstrated the expected nucleosome polymer "ladder", confirming that $\mathrm{M} \Phi$ death was mediated by apoptosis (not shown). MФ cultured alone demonstrated a low-level spontaneous apoptosis, as described by others [14]. The addition of anti-Fas increased apoptosis as measured by DNA fragmentation. In contrast to the effect on $M \Phi$, no cytotoxic effect was seen on HUVEC treated with up to $5 \mu \mathrm{g} / \mathrm{ml}$ anti-Fas, a saturating concentration of antibody as shown by fluoro-immunoassay (results not shown). These experiments were performed with and without IFN- $\gamma$ pretreatment to increase HUVEC Fas expression, with no inducible cytotoxicity. Additional experiments were performed to determine whether a cytotoxic effect of Fas ligation could be exposed by co-treatment with a range of other potentially cytotoxic agents. Exposing HUVEC to Fas antibody $(5 \mu \mathrm{g} / \mathrm{ml})$ did not have any additional effect on the cytotoxicity induced by treating HUVEC with cycloheximide or actinomycin $\mathrm{D}$ over a dose range from 0.0001 to $10 \mu \mathrm{g} / \mathrm{ml}$, and for times ranging from 4 to $24 \mathrm{~h}$.

The effect of anti-Fas was also compared on $M \Phi$ and HUVEC using flow cytometry to measure DNA fragmentation (Fig. 4). In agreement with the studies using ethid-

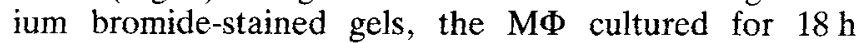
demonstrated a small population $(13 \%)$ spontaneously undergoing apoptosis (Fig. 4a). The addition of anti-Fas increased the proportion of cells with degraded DNA to
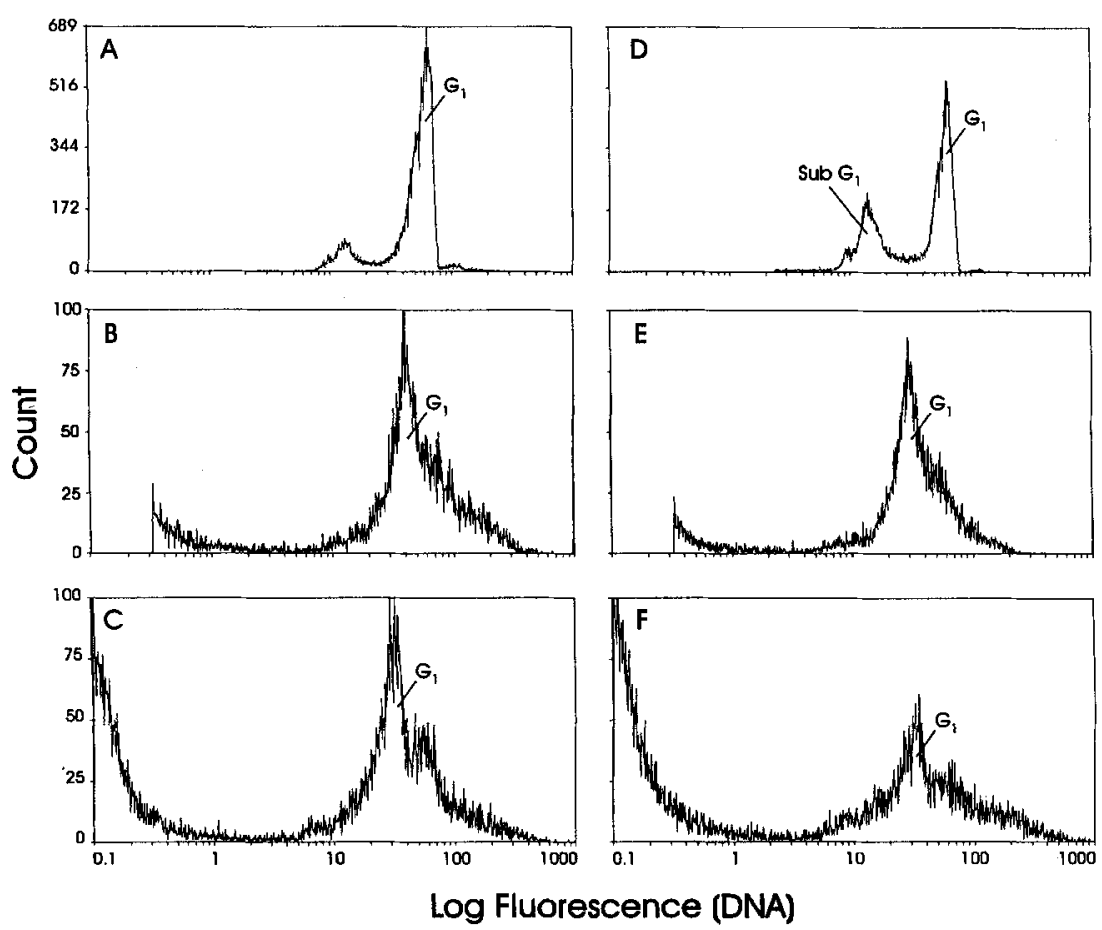

Figure 4. Flow-cytometric DNA analysis of the effects of anti-Fas on M $\Phi$ and HUVEC. (A) MФ were incubated with MOPC $104 \mathrm{e}$ for $18 \mathrm{~h}$, then incubated with PI and analyzed by flow cytometry. $G_{1}$ refers to cells in phase $G_{1}$ of the cell cycle. (B) HUVEC were incubated with $100 \mathrm{U} / \mathrm{ml} \mathrm{IFN}-\gamma$ for $18 \mathrm{~h}$ and anti- $\mu$ for $4 \mathrm{~h}$, then similarly treated. (C) IFN- $\gamma$-treated HUVEC were incubated with anti- $\mu$ for $18 \mathrm{~h}$ and similarly stained. (D) $M \Phi$ were incubated with antiFas for $18 \mathrm{~h}$. Sub $\mathrm{G}_{1}$ identifies the apoptotic population with less than $2 \mathrm{~N}$ DNA. (E) IFN$\gamma$-treated HUVEC were incubated with antiFas for $1 \mathrm{~h}$, washed, then incubated with antiIgM for $4 h$. (F) IFN- $\gamma$-treated HUVEC were incubated with anti-Fas for $1 \mathrm{~h}$, washed, then cultured with anti-IgM for $18 \mathrm{~h}$. No apoptosis is seen. 
$34 \%$. In contrast, $5 \mu \mathrm{g} / \mathrm{ml}$ anti-Fas did not induce apoptosis in IFN- $\gamma$ treated HUVEC at 4 (Fig. 4e) or $18 \mathrm{~h}$ (Fig. 4f). In these experiments, the anti-Fas was cross-linked with anti-IgM to address the possibility that the low epitope density of Fas on HUVEC prevented the cross-linking required to induce apoptosis [15].

Since HUVEC Fas did not transmit an apoptosis-inducing signal, we addressed the possibility that the anti-Fas antibody was detecting a non-Fas-related cross-reactive protein. Immunoblotting was used to confirm HUVEC Fas expression. Fig. 5 shows an immunoblot of untreated and IFN- $\gamma$ treated HUVEC, reacted with anti-Fas. The expected Fas antibody-reactive band at 43-kDa was seen on the HUVEC blots. No reactivity was seen in this or any other region with the use of an equivalent concentration of control IgM antibody. An additional band was seen at $105-\mathrm{kDa}$, consistent with a previous report of multiple immunoreactive isoforms of the Fas antigen [16]. The larger band was of considerably less intensity than the $43-\mathrm{kDa}$ band, but the significance of this is difficult to interpret due to the expected relatively incomplete transfer of high molecular weight proteins from the gel to the supporting membrane.

\section{a $\quad$ b $\quad c c c c$}

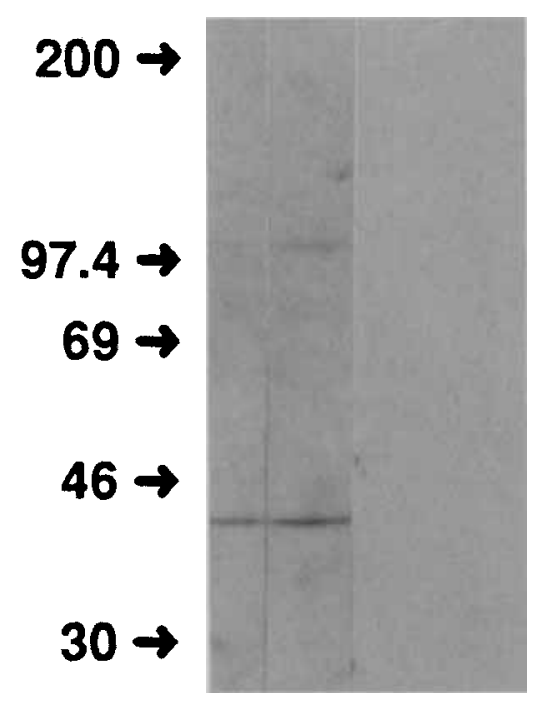

Figure 5. Immunoblots of HUVEC with anti-Fas. HUVEC were cultured in the presence or absence of IFN- $\gamma$ for $24 \mathrm{~h}$. Cell lysate protein was electrophoresed $(100 \mu \mathrm{g})$ through a $4-20 \%$ linear gradient SDS-PAGE gel, electrotransferred to nitrocellulose, and probed with either an IgM myeloma protein or anti-Fas. Lanes a and $\mathrm{c}$ : untreated HUVEC. Lanes b and d: IFN- $\gamma$-treated HUVEC. Lanes a and b: anti-Fas. Lanes $\mathrm{c}$ and $\mathrm{d}$ : control IgM.

\section{Discussion}

Previous investigators have demonstrated Fas expression by a variety of tissues and cell lines, including lymphocytes [17], heart, liver, lung, ovary [12], some hematopoietic [6] and non-hematopoietic cell lines [18], and a wide variety of epithelial cells [19]. Our experiments demonstrate that a subpopulation of HUVEC and freshly isolated monocytes/M $\Phi$ also constitutively express the Fas antigen. An earlier report used immunohistochemistry to show that the in situ microvasculature within the CNS, skeletal muscle and placenta express a variable amount of Fas [19], while endothelial cells from other tissues do not. The same authors also demonstrated that sinus histiocytes and "starry sky" $M \Phi$ expressed the Fas antigen, but freshly isolated monocytes/M $\Phi$ and HUVEC were not examined.

Fas expression on HUVEC and M $\Phi$ was increased by treatment with IFN- $\gamma$. The increase was not large in magnitude (two- to threefold), but was reproducible in serial experiments and using two imaging techniques. This finding is also consistent with other reports documenting the effects of IFN- $\gamma$ on Fas expression in other cells [12].

However, despite expression of Fas on HUVEC, and its up-regulation with IFN- $\gamma$, we were unable to induce endothelial apoptosis using anti-Fas. A similar finding has recently been reported in certain malignant cell lines [18] and in freshly isolated T and B cells [17]. It is clear that endothelial cells undergo apoptosis in some circumstances, such as stimulation with TNF [20], indicating that failure of Fas ligation to induce apoptosis is not due to an inherent inability of this cell type to undergo an apoptotic response. In the present studies, the concentration of anti-Fas used was greater than that needed to trigger apoptosis in human $M \Phi$, suggesting that failure to induce apoptosis was unlikely to be due to non-saturating amounts of anti-Fas. The possibility that Fas cross-linking was required, and that the low epitope density of Fas on HUVEC prevented cross-linking, was considered. However, adding anti-IgM to induce cross-linking had no effect on apoptosis, arguing against this possibility. Additional studies demonstrated no additive effect with cycloheximide or actinomycin D. Others have reported that the $\mathrm{Bcl}-2$ gene product can inhibit apoptosis induced by some signals [21], but more recent reports demonstrate that $\mathrm{Bcl}-2$ at best only partially inhibits Fas-induced apoptosis $[18,22]$, making this an unlikely explanation for our findings. A20 inhibits apoptosis, but is expressed only transiently in HUVEC following TNF treatment [23, 24]. Bcl-x also inhibits apoptosis [25], but is not expressed in HUVEC (V. Dixit, personal communication). At this time, the reason that Fas is expressed in HUVEC, but does not induce apoptosis, is unknown. Possibilities include a requirement for a second signal, that the endothelial Fas molecule expressed represents a variant and nonfunctional form of the Fas molecule, or that the cells express other molecules which could be inhibiting Fas-induced apoptosis. Since the integrity of the vascular endothelium is important to the normal functioning of blood vessels, it is perhaps not surprising that Fas function is tightly regulated, to prevent inadvertent cell death and subsequent vascular pathology.

In contrast to freshly isolated $\mathrm{B}$ and $\mathrm{T}$ cells and cultured endothelial cells, freshly isolated monocytes, as well as cultured monocytes $/ \mathrm{M} \Phi$, underwent apoptosis following Fas ligation. The reason why $\mathrm{M} \Phi$ should express a functional Fas molecule, while unstimulated T cells, B cells and cultured endothelial cells do not, is not completely clear. However, recent studies suggest a possible explanation. We have reported that $M \Phi$ die by apoptosis after activating $\mathrm{CD}^{+} \mathrm{T}$ cell clones [4]. We proposed that this mechanism is involved in both preventing continued activation of $\mathrm{CD} 4^{+}$ cells after the source of the initial antigenic challenge has 
been removed, and in preventing the accumulation of $M \Phi$ which would otherwise occur from the large number of monocytes produced daily by the bone marrow [26]. Since activated $T$ cells have recently been shown to express the Fas ligand [7], it is possible that MФ Fas is stimulated by $\mathrm{T}$ cells, triggering apoptotic death.

It is also possible that $\mathrm{T}$ cell-triggered $\mathrm{M} \Phi$ apoptosis has a pathogenic role in systemic lupus erythematosus (SLE). In contrast to recent findings in the MRL/lpr mouse [27], apoptosis actually appears to be increased in patients with active SLE. Numerous reports document that SLE patients have nucleosome-sized DNA fragments circulating in peripheral blood, and that PBMC from SLE patients will spontaneously release nucleosome-sized DNA fragments [28-32]. Furthermore, we have reported that $T$ cells from patients with active SLE will spontaneously lyse autologous $\mathbf{M} \Phi$ [11]. It is possible that Fas-ligand interactions occuring between T cells and $M \Phi$ contribute to the release of DNA fragments seen in these patients.

In summary, ligation of the Fas molecule has different effects on $M \Phi$ and endothelial cells. The differences in effects suggest that different mechanisms are involved in the elimination of these cells in vivo.

The authors would like to thank Dr. James Varani for providing HUVEC, Mr. David Brott, Mr. Paul Rowse and Mr. Forrest Hooper for their excellent technical help and Ms. Beverly Saunders for expert secretarial assistance.

Received June 2, 1994; in revised form July 28, 1994; accepted July 28, 1994.

\section{References}

1 Pober, J. S. and Cotran, R. S., Adv. Immunol. 1991. 50: 261.

2 Johnston, R. B., Jr., N. Engl. J. Med. 1988. 318: 747.

3 Mantovani, A., Bussolino, F. and Dejana, E., FASEB J. 1992. 6: 2591.

4 Richardson, B., Scheinbart, L., Strahler, J., Gross, L., Hanash, S. and Johnson, M., Arthritis Rheum. 1990. 33: 1665.

5 Gibbons, G. H. and Dzau, V. J., N. Engl. J. Med. 1994. 330. 1431.

6 Itoh, N., Yonehara, S., Ishii, A., Yonehara, M., Mizushima, S., Sameshima, M., Hase, A., Seto, Y. and Nagata, S., Cell 1991. 66: 233.

7 Suda, T., Takahashi, T., Golstein, P. and Nagata, S., Cell 1993. 75: 1169 .
8 Groenewegen, G., Buurman, W. A., van der Linden, C. J., Jeunhomme, G. M. and Kootstra, G., Transplantation 1985. 39: 657.

9 Jaffe, E. A., in Jaffe, E. A. (Ed.), Biology of Endothelial Cells, Martinus Nijhoff, The Hague 1984, p. 1.

10 Dixit, V. M., Marks, R. M., Sarma, V. and Prochownik, E.V., J. Biol. Chem. 1989. 264: 16905.

11 Richardson, B. C., Strahler, J. R., Pivirotto, T. S., Quddus, J., Bayliss, G. E., Gross, L. A., O'Rourke, K. S., Powers, D., Hanash, S. M. and Johnson, M. A., Arthritis Rheum. 1992. 35: 647.

12 Watanabe-Fukunaga, R., Brannan, C. I., Itoh, N., Yonehara, S., Copeland, N. G., Jenkins, N. A. and Nagata, S., J. Immunol. 1992. 148: 1274.

13 Johnson, D. R. and Pober, J. S., Proc. Natl. Acad. Sci. USA 1990. 87: 5183.

14 Mangan, D. F. and Wahl, S. M., J. Immunol. 1991. 147: 3408 .

15 Dhein, J., Daniel, P.T., Trauth, B. C., Oehm, A., Moller, P. and Krammer, P. H., J. Immunol. 1992. 149: 3166.

16 Yonehara, S., Ishii, A. and Yonehara, M., J. Exp. Med. 1989. 169: 1747

17 Miyawaki, T., Uehara, T., Nibu, R., Tsuji, T., Yachie, A., Yonehara, S. and Taniguchi, N., J. Immunol. 1992. 149: 3753.

18 Owen-Schaub, L. B., Radinsky, R., Kruzel, E., Berry, K. and Yonehara, S., Cancer Res. 1994. 54: 1580.

19 Leithauser, F., Dhein, J., Mechtersheimer, G., Koretz, K., Bruderlein, S., Henne, C., Schmidt, A., Debatin, K. M., Krammer, P. H. and Moller, P., Lab. Invest. 1993. 69: 415.

20 Robaye, B., Mosselmans, R., Fiers, W., Dumont, J. E. and Galand, P., Am. J. Pathol. 1991. 138: 447.

21 Hockenbery, D. M., Oltvai, Z. N., Yin, X. M., Milliman, C. L. and Korsmeyer, S. J., Cell 1993. 75: 241.

22 Itoh, N., Tsujimoto, Y. and Nagata, S., J. Immunol. 1993. 151: 621.

23 Dixit, V. M., Green, S., Sarma,V., Holzman, L. B., Wolf, F.W., O'Rourke, K., Ward, P. A., Prochownik, E. V. and Marks, R. M., J. Biol. Chem. 1990. 265: 2973.

24 Opipari, A.W., Jr., Hu, H. M., Yabkowitz, R. and Dixit,V. M., J. Biol. Chem. 1992. 267: 12424.

25 Boise, L. H., Gonzalez-Garcia, M., Postema, C. E., Ding, L., Lindsten, T., Turka, L. A., Mao, X., Nunez, G. and Thompson, C. B., Cell 1993. 74: 597.

26 Meuret, G., Bammert, J. and Hoffmann, G., Blood 1974. 44: 801.

27 Watanabe-Fukunaga, R., Brannan, C. I., Copeland, N. G., Jenkins, N. A. and Nagata, S., Nature 1992. 356: 314.

28 Emlen, W., Niebur, J. and Kadera, R., J. Immunol. 1994. 152: 3685.

29 Compton, L. J., Steinberg, A. D. and Sano, H., J. Immunol. 1984. 133: 213.

$30 \mathrm{Li}$, J. Z. and Steinman, C. R., Arthritis Rheum. 1989. 32: 726.

31 McCoubrey-Hoyer, A., Okarma, T. B. and Holman, H. R., Am. J. Med. 1984. 77: 23.

32 Fournie, G. J., Kidney Int. 1988. 33: 487. 